\title{
Quality, value, satisfaction and loyalty amongst race groups: A study of customers in the South African fast food industry
}

\author{
N.S. Terblanche* and C. Boshoff \\ Department of Business Management, University of Stellenbosch, \\ Stellenbosch 7600, Republic of South Africa \\ nst@sun.ac.za
}

Received January 2010

\begin{abstract}
The retention of customers has become a key concern for many businesses. Various drivers of loyalty such as satisfaction, loyalty and commitment have, over time, been studied with the objective to improve customer retention. This study reports on the empirical findings in respect of the relationships between various dimensions of a loyalty model for the South African fast food sector and considers differences amongst race groups in respect of perceived quality, value, satisfaction and loyalty.
\end{abstract}

Respondents in this empirical study were consumers drawn randomly from the seven major metropolitan areas of South Africa. The respondents are all customers of a national firm in the South African fast food sector and they were required to respond to items from (mostly) the American Customer Satisfaction Index (ACSI) scales. The empirical findings provide support for the theoretical model proposed but there is not much difference in how the various race groups' loyalty intentions are shaped.

*To whom all correspondence should be addressed.

\section{Introduction}

According to Coyles and Gokey (2005) “.... it costs far less to hold on to a customer than to acquire a new one. That is why customer retention has become the Holy Grail in industries ....." Customer retention has grown in importance for most businesses as it has been acknowledged as an essential contributor to profitability over the long term (Anderson \& Sullivan, 1993; Fornell, 1992; Iniesta \& Sánchez, 2002; Heskett, Sasser \& Schlesinger, 1997; Heskett, 2002; Dick \& Basu, 1994; Anderson, Fornell \& Lehmann, 1994).

Various constructs have been studied as means to try and ensure customer retention. Satisfaction, loyalty and commitment of customers are probably the three constructs that have been studied the most in an effort to try and understand the drivers of customer retention. These constructs have received extensive coverage in academic journals during the past decade (Oliver, 1999; Auh \& Johnson, 2005; Wetzels, De Ruyter \& Van Birgelen, 1998). It is especially the relationships between satisfaction and loyalty and between satisfaction and commitment that have been reported extensively on in the academic literature (Oliver, 1999; Clerfeuille \& Poubanne, 2003).

Despite the absence of a generally-accepted measure to represent customer retention, customer retention has grown in importance as the key to many firms' financial performance and survival. It has always been a challenge for retailers to find explanations for customers' "unpredictable behaviour”. Knox and Denison (2000), for example, are of the opinion that the introduction of impersonal, self-service systems may have persuaded many consumers to become more inconsistent in their shopping behaviour and loyalty to a particular retailer. Various perspectives of customer retention research suggested that customer retention leads to increased long-term profitability, lower sales and marketing costs, an increase in the opportunities for cross-selling of products and services and positive word-of-mouth by customers (Grönroos, 1990; Reichheld, 1996; Kent \& Löfmarck Vaghult, 2000; Wirtz \& Lihotzky, 2003). In this study customer loyalty serves as a proxy for customer retention.

\section{Purpose of the study}

The primary objectives of this study are twofold. The first objective was to ascertain whether selected constructs impact on customer loyalty to a firm competing in the South African fast food industry. The second objective of the study was to determine whether clients from different racial groups differ in their perceptions of the quality, value, satisfaction and loyalty to the firm. 


\section{The theoretical framework of the study}

Four constructs were investigated in the study. The primary focus was on the relationships between perceived quality, perceived value, satisfaction and the loyalty of customers.

\section{Customer loyalty}

Customer loyalty is the dependent variable in our model in view of its value as a surrogate for customer retention and its well-proven contribution to profitability (ACSI, 2001; Fornell, Johnson, Anderson, Cha \& Bryant, 1996; Johnson, Gustafson, Andreasen, Lervik \& Cha, 2001). Customer loyalty can be defined as a "deeply-held commitment to rebuy or re-patronize a preferred product/service consistently in the future, thereby, causing repetitive same brand set purchasing, despite situational influences and marketing efforts having the potential to cause switching behavior" (Oliver, 1999). Customer loyalty can be defined from a behavioral, attitudinal or situational perspective (Chaudhuri \& Holbrook, 2001; Uncles, Dowling \& Hammond, 2003). Behavioral loyalty is articulated as purchase and usage behaviour displayed by customers in their historical purchasing and use of a brand and competing brands. Attitudinal loyalty is normally displayed by an enduring (emotional) bond with a brand and strong customer preferences for the brand. Situational loyalty, in contrast to behavioral and attitudinal loyalty, is dependent on the shopping and purchasing situation. Although all three types of loyalty have a role to play in marketing, most firms would prefer that their customers' loyalty is attitudinal because of the emotional element.

\section{Customer satisfaction}

Customer satisfaction, according to Fornell et al. (1996:8), lies at the core of a sequence of relationships, including the antecedents of customer satisfaction (perceived quality and perceived value) as well as the consequence of customer satisfaction (loyalty). Satisfaction in this study refers to cumulative satisfaction which includes all of a customer's experiences over time with a product or service provider (Johnson \& Fornell, 1991). A study by Olsen and Johnson (2003: 193-194) ascertained that the variation explained in loyalty increased from 35\% and 34\% for transaction-specific samples to $45 \%$ and $63 \%$ for cumulative samples. A further important advantage of cumulative satisfaction over a more transaction-specific view, is that cumulative satisfaction is better able to predict the future behaviour of customers and the economic performance of the firm (Fornell, et al., 1996; Johnson, et al., 2001).

Customer satisfaction has been credited with several beneficial outcomes. Fornell, Mithas, Morgeson III and Krishon (2006:4) furnish a long list of published research which confirms the positive relationship between customer satisfaction and outcomes such as:

(a) loyalty, usage behaviour, positive word of mouth; and

(b) reduced cost of future transactions, reduced costs related to warranties, complaints, defective goods and field service.
In this study, the primary focus is on customer satisfaction and its relationship with customer loyalty. Based on the preceding discussion, the following hypothesis is formulated:

$\mathbf{H}_{\mathbf{1}}$ : There is a positive relationship between customer satisfaction and customer loyalty in the South African fast food sector

\section{Perceived quality}

Johnson and Ettlie (2001:194) describe perceived quality as the result of product performance which in turn can be labelled as the degree of customisation and freedom from defects, or how reliably the product meets customer requirements. Reliability had been found to be relatively more important for service satisfaction than product satisfaction (Johnson \& Nilsson, 2000). Dabholkar, Shepherd and Thorpe (2000) point out that researchers have questioned the causal order of perceived quality and customer satisfaction. Contradictions in the definitions and measurements of quality and customer satisfaction resulted in contradictory findings in respect of the relationship between quality and satisfaction (Choi \& Eboch, 1998; Hardie, 1998; Sousa \& Voss, 2002). This earlier confusion has been cleared by more recent research that confirms a clear pattern in which satisfaction is the behavioural consequence of quality (Green \& Boshoff, 2002:12; Gallarza \& Saura, 2006:448). In the present study, as in the ACSI model, it is hypothesised that the greater the perceived quality, the greater the level of customer satisfaction (ACSI, 2001:12). This conclusion is supported by the theoretical perspective which claims that customer satisfaction is an outcome of consumers' positive evaluations of the quality of products and services (Babakus, Bienstock \& Van Scotter, 2004:718; Liu, 2005:433). Perceived quality has also been found to have a significant effect on perceived value (Dodds, Monroe \& Grewal, 1991). In a similar vein, it has also been established that product value was enhanced by marketing communications that emphasise the relative higher quality of a product (Rangaswamy, Burke \& Oliva, 1993). Last, but not least, it has been found that, under different conditions, quality had a significant influence on how service value is perceived (Ostrom \& Iacobucci, 1995). Earlier research is thus in agreement that perceived quality at the time of purchase influence perceived value. We expected the product and service quality dimensions of ACSI to be highly correlated and undertook an exploratory factor analysis which confirmed that the two dimensions are indeed one. In this study the product and service quality dimensions are thus combined and labelled as perceived quality. Based on the research findings that satisfaction is the behavioural outcome of quality, the following hypothesis is suggested:

$\mathbf{H}_{2}$ : There is a positive relationship between perceived quality and customer satisfaction in the South African fast food sector

\section{Perceived value}

The nineties saw the introduction and development of a research approach in which the interpretation of consumer 
behaviour is enhanced when it is analysed from a perceived value perspective (Nilson, 1992; Ostrom \& Iacobucci, 1995; Jensen, 1996; Woodruff \& Gardial, 1996; Heskett et al., 1997). Gallarza and Saura (2006:438) believe that the value concept is "multi-faceted and complex" because the term value is "extremely abstract and polysemous in nature".

Value is usually perceived as utilitarian and/or hedonic in nature. Sweeney and Soutar (2001:216) developed a scale to measure value which consists of four dimensions and included both utilitarian and hedonic components. MacKay (1999:182) stressed the value of combining utilitarian and hedonic components by articulating the appeal of a product or service is an "amalgam of rational and emotional factors”.

Unfortunately consumers, researchers and practitioners have assigned dissimilar meanings to value over time (Zeithaml, 1988; Lai, 1995; Woodruff \& Gardial, 1996). Zeithaml and Bitner (1996:3) see value as an amorphous concept. Lin, Sher and Shih (2005:333) suggested, after an extended analysis of the literature on value, that perceived value should be described as a second-order multi-dimensional formative construct. Lin et al. (2005), in an e-commerce environment, identified five dimensions of perceived value namely monetary sacrifice, web site design, fulfilment/reliability, security/privacy and customer service.

The myopic view that customer value may not extend beyond the price-quality trade-off has also been turned upside down by research in different fields (Kumar \& Grisaffe, 2004:46). Holbrook (1996), who approached customer value from the philosophical field of axiology (theory of value), proposed a typology of eight different types of customer value. The eight different types of customer value are:

- $\quad$ excellence (quality),

- $\quad$ efficiency (convenience)

- $\quad$ status (success)

- $\quad$ esteem (reputation)

- $\quad$ play (fun)

- $\quad$ aesthetics (beauty)

- $\quad$ ethics (virtue/morality); and

- $\quad$ spirituality (faith)

All Holbrook's value-types centre on what a customer can "get” from a product or service. Zeithaml's (1988) conceptualised value as having both a "get" and a "give" element. Despite the apparent differences in the conceptualisation of perceived value, the importance of perceived value in marketing is exemplified by the views of several authors who anticipate that perceived value will increase in importance in the this century (Woodruff, 1997; Forester, 1999; Treadgold, 1999:45). The preceding discussion leads to the following two hypotheses:

$\mathbf{H}_{3}$ There is a positive relationship between perceived quality and perceived value in the South African fast food sector
$\mathbf{H}_{4}$ There is a positive relationship between perceived value and customer satisfaction in the South African fast food sector

\section{Perception differences amongst racial groups}

Studies in the USA found that race and ethnicity play an important role in consumer decision-making (Podoshen, 2008:211). Several studies also found that Black Americans patronise fast food outlets more than any of the other race groups (Cavallaro, 2008:8). The popularity of fast food amongst Black people is also illustrated by the number of fast food outlets in the Black neighbourhoods when compared to predominantly White neighbourhoods (Kwate, 2008:32). A study undertaken in 2004 found that the Black neighbourhoods had 2.4 fast food outlets per square mile whilst the White neighbourhoods had 1.5 fast food outlets per square mile (Block, Scribner \& DeSalvo, 2004). As Black townships in South Africa were traditionally developed as dormitory towns with the minimum of shopping and other amenities, it is highly unlikely that the prevalence of fast food outlets in the Black townships would be nearly as many as those in the White towns and cities because of the location earlier restrictions imposed by the repealed Group Areas Act. Although the Group Areas Act have been repealed some time ago, it is fairly safe to state that the geographical location of the different race groups have not changed substantially since the repeal of the Group Areas Act.

The second objective of the study was to determine whether clients from different racial groups differ in their perceptions of the quality, value, satisfaction and loyalty towards a fast food chain. This information could be useful for fast food businesses as the geographical location of the different races could be of use for the design of outdoor promotion and advertising strategies aimed at the particular race groups. The racial classification used by the South African government was also used for racial identification purposes in this study. The groups are Blacks, Coloureds, Indians and Whites. The followings hypothesis is investigated:

$\mathbf{H}_{\mathbf{0}}$ : The mean scores of the perceptions of quality, value, satisfaction and loyalty of the four different racial groups are equal

\section{Research design}

The dimensions measured empirically were perceived product quality, perceived service quality, perceived value, customer satisfaction and customer loyalty. The items measuring each of these variables were all linked to 10 point semantic differential scales where a 10 meant a very positive perception and/or attitude. Table 1 contains the semantic differential scales as well as the latent variables and manifest variables investigated in the study. 
Table 1: Latent and manifest variables

\begin{tabular}{|c|c|}
\hline $\begin{array}{c}\text { Latent Variables } \\
\text { (Dimensions) }\end{array}$ & Manifest Variable(Items) \\
\hline Perceived quality & $\begin{array}{l}\text { - Please consider all your experiences in the last } 3 \text { months with ABC. Using a } 10 \text {-point scale, on which } 1 \text { means } \\
\text { 'not very high' and } 10 \text { means 'very high', how would you rate the overall quality of your meal purchased at } \\
\text { - ABC? } \\
\text { - Now please consider all your experiences in the last } 3 \text { months with the service you received from ABC. Using a } \\
10 \text {-point scale, on which } 1 \text { means 'not very high' and } 10 \text { means 'very high', how would you rate the overall } \\
\text { quality of service you have received from ABC? } \\
\text { - Now thinking about your personal requirements for a meal from ABC, such as the right temperature, ample } \\
\text { portion size, tastiness or continuous quality. Using a } 10 \text {-point scale, on which } 1 \text { now means 'not very well' and } \\
10 \text { means 'very well', how well has ABC actually met your personal requirements? } \\
\text { - Now thinking about your personal requirements for service from ABC, such as good looking furniture and } \\
\text { counters, competent staff, speed of delivery or service (waiting time) or presentation of the meal. Using a } 10 \text { - } \\
\text { point scale on which } 1 \text { now means 'not very well' and } 10 \text { means 'very well', how well has the service from ABC } \\
\text { actually met your personal requirements? } \\
\text { Now please think about how often things go wrong with a meal from ABC, regarding such things as taste, } \\
\text { portion size, wrong temperature or appearance. Use a } 10 \text {-point scale, on which } 1 \text { now means 'very often' and } 10 \\
\text { means 'not very often', how often have things gone wrong with your meal? } \\
\text { Now please think about how often things go wrong with the service at ABC, regarding such things as long } \\
\text { waiting time, incompetent staff or unneat counters, tills and uniforms. Using a } 10 \text {-point scale, on which } 1 \text { now } \\
\text { means 'very often' and } 10 \text { means 'not very often', how often have things gone wrong with the service for your } \\
\text { meal? }\end{array}$ \\
\hline Perceived value & $\begin{array}{l}\text { - Given the quality of your meal at ABC, how would you rate the price that you paid for your meal? Please use a } \\
10 \text {-point scale, on which } 1 \text { means 'very poor price given the quality' and } 10 \text { means 'very good price given the } \\
\text { quality'. } \\
\text { - Given the price that you paid for your meal at ABC, how would you rate the quality of your meal? Please use a } \\
\text { 10-point scale, on which } 1 \text { means 'very poor quality given the price' and } 10 \text { means 'very good quality given the } \\
\text { price' }\end{array}$ \\
\hline Customer satisfaction & $\begin{array}{l}\text { - First, please consider all your experiences to date with ABC. Using a 10-point scale on which } 1 \text { means 'very } \\
\text { dissatisfied' and } 10 \text { means 'very satisfied', how satisfied are you with ABC? } \\
\text { - Considering all the expectations that we have discussed, to what extent has your ABC fallen short of your } \\
\text { expectations or exceeded your expectations? Using a 10-point scale, on which } 1 \text { now means 'falls short of your } \\
\text { expectations' and } 10 \text { means 'exceeds your expectations', to what extent has ABC fallen short of or exceeded } \\
\text { your expectations? } \\
\text { - Forget ABC for a moment. Now, I want you to imagine an ideal fast food outlet or restaurant chain. How well } \\
\text { do you think ABC compares with that ideal fast food outlet or restaurant chain? Please use a 10-point scale, on } \\
\text { which } 1 \text { means 'not very close to the ideal' and } 10 \text { means 'very close to the ideal'. }\end{array}$ \\
\hline Customer loyalty & $\begin{array}{l}\text { - The next time you are going to purchase a meal from a fast food outlet or restaurant chain, how likely is it that it } \\
\text { will be ABC again? Using a 10-point scale, on which } 1 \text { means 'very unlikely' and } 10 \text { means 'very likely', how } \\
\text { likely is it that it will be ABC again? } \\
\text { - Think about everything that require from a fast food outlet to keep on patronising it, and then rate ABC, where } \\
10 \text { means that you'll definitely patronise it in the future and } 1 \text { means that you'll definitely not patronise it in the } \\
\text { future. }\end{array}$ \\
\hline
\end{tabular}

\section{Data collection}

A structured questionnaire was used to collect data during interviews with respondents. All interviews were conducted using random suburb sampling to obtain a representative national sample. Suburbs were drawn from the 2001 South African census and five interviews were conducted within each selected suburb to ensure that a demographically representative sample was realised across suburbs and geographic areas. The total sample for this study was 533 interviews. Interviews were conducted in the seven major metropolitan areas of South Africa and the sample is in the same proportions of the South African population in terms of both ethnic group and gender. Respondents were interviewed in-home and had to be 18 years or older to qualify for the interview and they also had to have bought a meal form a fast food restaurant in the month preceding the interview.

\section{Empirical results}

The instrument used in the study was mainly based on items of the ACSI scale. The major differences between the scale used in this study and the ACSI scale are that the dimensions of Customer Expectations and Customer Complaints were excluded. Customer Expectations were left out because we were of the opinion that if a respondent is asked her/his expectations and experiences in the same interview, the response in respect of expectations is tainted/influenced by what was experienced. Very few (less than one percent of the respondents), reported that they complained to store staff or managers and because of the low prevalence of complaining we could not find any relationship between complaints and Customer Satisfaction/Customer Loyalty.

A variety of statistical tests were used to analyse the data. The statistical tests included a confirmatory factor analysis (CFA), a structural equation model (SEM) and an analysis of variance (ANOVA). Except for the analysis of variance 
the data in respect of all the races were lumped together and analysed at the aggregate level.

The assessment of the internal consistency of each dimension was conducted as suggested by Churchill (1979). All the Cronbach alpha co-efficients of the dimensions as well as the scale used to measure customer loyalty were above the generally accepted cut-off value of 0.7 (Nunnally \& Bernstein, 1994). The reliability results are summarised in Table 2.

\section{Table 2: Reliability results}

\begin{tabular}{l|c}
\hline Perceived quality & 0,987 \\
\hline Perceived value & 0,986 \\
\hline Customer satisfaction & 0,978 \\
\hline Customer loyalty & 0,969 \\
\hline Overall & 0,994 \\
\hline
\end{tabular}

The primary objectives of this study were twofold. The first objective was to ascertain whether the selected factors impact on customers' loyalty to the fast food provider. Structural equation modeling (SEM) was used to estimate the relationships in the model in Figure 1. The second objective of the study was to assess whether clients from different racial groups differ in their perceptions of the quality, value, satisfaction and loyalty to the fast food provider. To test the hypothesis that the mean scores of the perceptions of quality, value, satisfaction and loyalty of the four different racial groups are equal, an analysis of variance (ANOVA) to test for differences between racial groups and Scheffe post hoc tests for multiple comparisons were conducted.

The theoretical model in Figure 1 was assessed by means of structural equation modeling using LISREL 8,80 (Jöreskog \& Sörbom, 2006). As it emerged that the data were not normally distributed, the Robust Maximum-Likelihood (RML) estimation method was used to test the theoretical model. Therefore it is not appropriate to report the GFI and AGFI indices. Figure 1 illustrates the empirical relationships between the dimensions studied.

The results in Table 3 suggest a moderate fit of the model to the data $(\chi 2=352,24 ; \mathrm{df}=61$; RMSEA $=0,0748$; and ECVI $=0,569$.

\section{Table 3: Model fit indices}

\begin{tabular}{l|l}
\hline Degrees of Freedom & 61 \\
\hline Minimum fit Chi-square & $352,24(\mathrm{p}=0,0)$ \\
\hline Satorra-Bentler Scaled Chi-square & 242,51 \\
\hline RMSEA & 0,0748 \\
\hline ECVI & 0,569 \\
\hline
\end{tabular}

Figure 1 shows that all the relationships between the different dimensions are in the direction predicted by the hypotheses. The relationships between customer satisfaction and customer loyalty, perceived value and customer satisfaction, perceived quality and perceived value, perceived quality and customer satisfaction are strong and highly significant (Table 4). Hypotheses 1, 2, 3 and 4 are thus supported.
Table 4: Path co-efficients for the model in Figure 1

\begin{tabular}{c|c}
\hline PATH & $\begin{array}{c}\text { Path co-efficients } \\
\text { (t-value) }\end{array}$ \\
\hline CUSTOMER SATISFACTION $\rightarrow$ & 0,98 \\
LOYALTY & $(19,52)^{* * *}$ \\
\hline PERCEIVED VALUE $\rightarrow$ CUSTOMER & 0,57 \\
SATISFACTION & $(8,68)^{* * *}$ \\
\hline PERCEIVED QUALITY $\rightarrow$ & 0,79 \\
PERCEIVED VALUE & $(16,84)^{* * *}$ \\
\hline PERCEIVED QUALITY $\rightarrow$ & 0,45 \\
CUSTOMER SATISFACTION & $(6,72)^{* * *}$ \\
\hline$* * * \quad$ &
\end{tabular}

To address the second objective a series of four analyses of variance (ANOVAS) tests were conducted. In each case racial classification was the independent variable. The four dependent variables were loyalty, perceived quality, customer satisfaction and value respectively.

The objective of the first analysis of variance was to assess the differences amongst the race groups in terms of loyalty. The resultant F-value of 6.450 suggested that the null hypothesis that the mean scores amongst the race groups is equal, had to be rejected. The post hoc test (Scheffe) revealed that the mean loyalty score of White customers (8.4706) differed significantly $(\mathrm{p}<0.01)$ from the mean score of Black customers. The Scheffe test also revealed that the mean loyalty score of White customers (8.4706) differ significantly from that of Coloured customers (9.1382) of the fast food chain.

The analysis of variance undertaken to assess the differences amongst race groups in terms of perceived quality (dependent variable) produced a F-value of 4.393 which suggested that the null hypothesis that the mean scores amongst the race groups are equal, had to be rejected. The post hoc test (Scheffe) revealed that the mean perceived quality score of Coloured customers (8.6565) differed significantly $(\mathrm{p}<0.01)$ from the mean score of Black customers. Coloured customers thus rate the quality of the fast food provider products and services significantly higher than Blacks.

The analysis of variance test to assess the differences amongst race groups in terms of customer satisfaction (dependent variable) did not provide any significant differences between the four race groups as the F-value was 2.013 ( $p>0.05$ ). The null hypothesis that the mean scores of customer satisfaction of the four different racial groups are equal, thus could not be rejected.

The analysis of variance undertaken to assess the differences amongst race groups in terms of perceived value (dependent variable) produced an F-value of 6.565 which suggests that the null hypothesis of the mean scores amongst the race groups are equal, had to be rejected. The post hoc test (Scheffe) revealed that the mean perceived value score of Coloured customers (8.9996) were significantly higher than the mean scores of White customers $(p<0.001 ; 8.2134)$, Black customers $(\mathrm{p}<0,01 ; 8,3919)$ and Indian customers $(\mathrm{p}<$ $0,05 ; 8,2235)$. 


\section{Discussion and conclusion}

The findings of this study enhance our understanding of the antecedents of customer loyalty. Both perceived quality and perceived value are important for customer satisfaction in the fast food industry. Customer satisfaction, in turn, appears to be a good predictor of customer loyalty. These findings support and contradict previous research findings on the relationship between customer satisfaction and customer loyalty. Some authors have found that not all satisfaction convert to customer loyalty (Mittal \& Lassar, 1998). In other studies it was found that customer satisfaction does not impact on customer loyalty or that the characteristics of customers have different thresholds that, at similar levels of satisfaction ratings, result in different repurchase rates (Miranda, Kónya \& Havrila, 2005; Andreasen \& Lindestad, 1998; Mittal \& Kamakura, 2001). The prediction of changes in repurchase behaviour, based on changes in satisfaction ratings has also been found to be misleading when intention ratings are used (Mittal \& Kamakura, 2001: 140). Hart and Johnson (1999) suggested that trust, being a stronger emotion than satisfaction, may better predict customer loyalty than customer satisfaction.

The results related to the second objective of the study, namely how clients from different racial groups differ in their perceptions of the quality, value, satisfaction and loyalty of the fast food provider, produced some interesting findings that could be of value to managerial practice. Significant differences exist amongst the loyalty scores of Black, Coloured and Indian customers of the fast food provider. Coloured customers are the most loyal group of customers, followed by Black customers.

As far as perceived quality is concerned the highest rating of the fast food provider emanated from the Coloured customers. No significant differences could be found amongst the racial groups in terms of their perception of satisfaction with the fast food provider. The Coloured customers of the fast food provider also rated the perceived value of the fast food provider products significantly higher than the other racial groups.

\section{Managerial implications}

The differences in the mean loyalty scores, although statistically significant, do not warrant a different marketing strategy for each of the four racial groups as the raw mean values are all relatively high and range from 8,47 to 9,1 out of 10 for the four racial groups. The four racial groups also differed significantly in respect of how they perceived the quality and value offered by the fast food provider. No meaningful differences in respect of all the respondents' satisfaction with the fast food provider could be found.

What is important from a managerial viewpoint is that the fast food provider should determine in more precise and detailed terms, what makes their customers satisfied and loyal. A major challenge for managers is that although their customers might say that they are satisfied, they often still switch to other brands or stores. Satisfied customers are thus not necessarily loyal customers. Loyalty demands an attitudinal predisposition from the customer that sheer satisfaction cannot persistently bring into being. The bottom line is that customer satisfaction measures are insufficient per se and need to be augmented by a degree of loyalty. In the final analysis it seems appropriate to at least focus on those elements that create satisfaction as such elements do impact positively on loyalty.

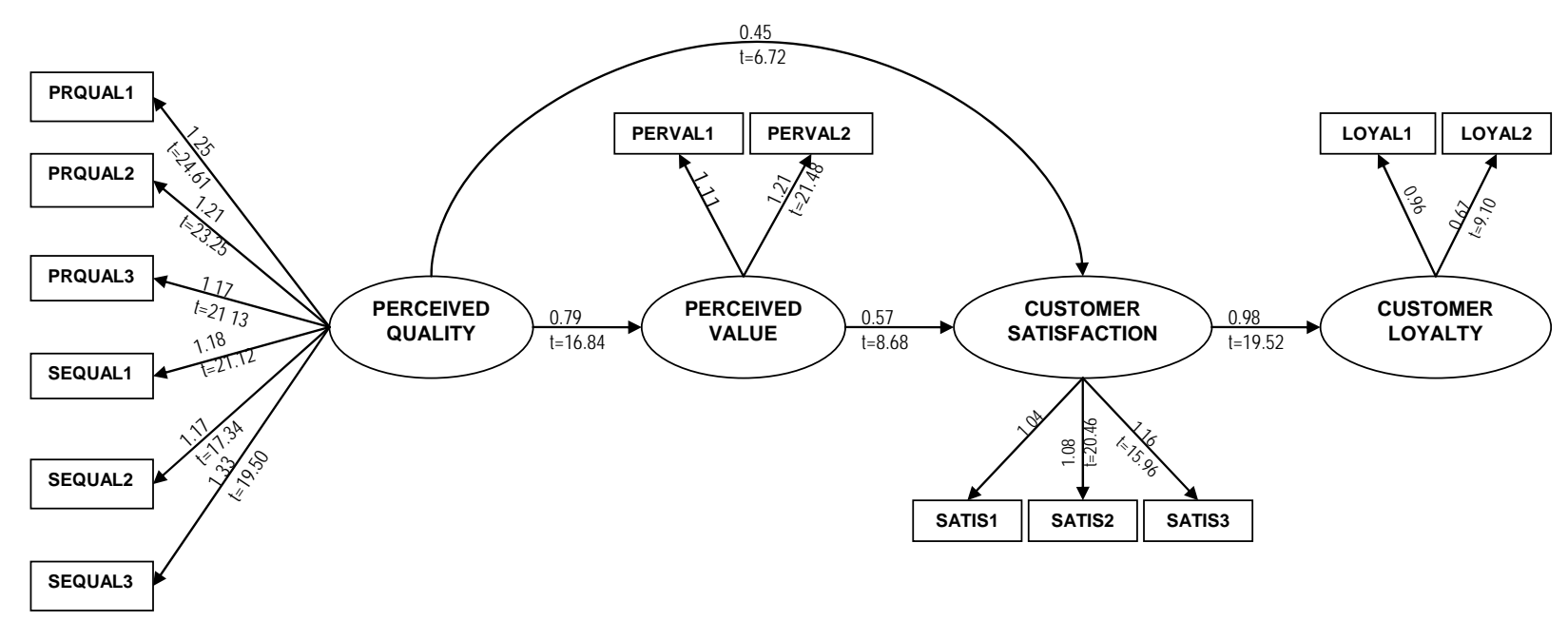

Figure 1: Empirical results 


\section{References}

American Customer Satisfaction Index. 2001. Methodology report. Ann Arbor, MI: The Regents of the University of Michigan.

Anderson, E. W., Fornell, C. \& Lehmann, D. R. 1994. 'Customer satisfaction, market share, and profitability: Findings from Sweden’, Journal of Marketing, 58(3): 53-66.

Anderson, E.W. \& Sullivan, M.W. 1993. 'The antecedents and consequences of customer satisfaction for firms', Marketing Science, 12(2): 125-43.

Andreasen, T.W. \& Lindestad, B. 1998. 'Customer loyalty and complex services: The impact of corporate image on quality, customer satisfaction and loyalty for customers with varying degrees of service expertise', International Journal of Service Industry Management, 9(1): 7-23.

Auh, S. \& Johnson, M.D. 2005. 'Compatibility effects in evaluations of satisfaction and loyalty', Journal of Economic Psychology, 26(1): 35-57.

Babakus, E., Bienstock, C.C. \& Van Scotter, J.R. 2004. 'Linking perceived quality and customer satisfaction to store traffic and revenue growth’, Decision Sciences, 35(4): 713737.

Block, J.P., Scribner, R.A. \& DeSalvo, K.B. 2004. 'Fast food, race/ethnicity, and income - A geographic analysis', American Journal of Preventive Medicine, 27(3): 211-217.

Cavallaro, M. 2008. 'The African-American food dollar Where it goes and how to get a piece of it', Restaurant Business, 27(8): 8-9.

Chaudhuri, A. \& Holbrook, M.B. 2001. 'The chain of effects from brand trust and brand affect to brand performance: The role of brand loyalty', Journal of Marketing, 65(2): 81-94.

Choi, T.Y. \& Eboch, K. 1998. 'The TQM paradox: Relations among TQM practices, plant performance, and customer satisfaction', Journal of Operations Management, 17(1): 59-75.

Churchill, G.A., Jr. 1979. 'A paradigm for developing better measures of marketing constructs', Journal of Marketing Research, 16(1): 64-73.

Clerfeuille, F. \& Poubanne, Y. 2003. 'Differences in the contributions of elements of service to satisfaction, commitment and consumers' share of purchase: A study from the tetraclass model', Journal of Targeting, Measurement and Analysis for Marketing, 12(1): 66-81.

Coyles, S. \& Gokey, T.C. 2005. 'Customer retention is not enough', Journal of Consumer Marketing, 22(2): 101-105.

Dabholkar, P.A., Shepherd, C.D. \& Thorpe, D.I. 2000. 'A comprehensive framework for service quality: An investigation of critical conceptual and measurement issues through a longitudinal study', Journal of Retailing, 76(2): 139-173.

Dick, A. S. \& Basu, K. 1994. 'Customer loyalty: Towards an integrated framework', Journal of the Academy of Marketing Science, 22(2): 99-113.

Dodds, W. B., Monroe, K. B. \& Grewal, D. 1991. 'Effects of price, brand and store information on buyers' product evaluations', Journal of Marketing Research, 28(3): 307319.

Forester, M. 1999. 'Déjà vu discussion delivers message emphasizing value’, Chain Store Age, 75 (4):12.

Fornell, C. 1992. 'A national customer satisfaction barometer: The Swedish experience', Journal of Marketing, 55(1):1-21.

Fornell, C., Johnson, M.D., Anderson, E.W., Cha, J. \& Bryant, B.E. 1996. 'The American customer satisfaction index: Nature, purpose, and findings', Journal of Marketing, 60(4): 7-18.

Fornell, C., Mithas, S., Morgenson III, F.V. \& Krishnan, M.S. 2006. 'Customer satisfaction and stock prices: High return, low risk’, Journal of Marketing, 70(1): 3-14.

Gallarza, M.G. \& Saura, I.G. 2006. 'Value dimensions, perceived value, satisfaction and loyalty: An investigation of university student's travel behaviour', Tourism Management, 27(3): 437-452.

Green, S. \& Boshoff, C. 2002. 'An empirical assessment of the relationships between service quality, satisfaction and value: A tourism study', Management Dynamics: Contemporary Research, 11(3):2-16.

Grönroos, C. 1990. Services management and marketing: Managing the moments of truth in service competition. Lexington, M.A.: Lexington Books.

Hardie, N. 1998. 'The effects of quality on business performance', Quality Management Journal, 5(3): 65-83.

Hart, C.W. \& Johnson, M.D. 1999. 'Growing the trust relationship’, Marketing Management, Spring:8-19.

Heskett, J.L. 2002. 'Beyond customer loyalty', Managing Service Quality, 12(6): 355-357.

Heskett, J.L., Sasser, W.E. (Jr) \& Schlesinger, L.A. 1997. The service profit chain. How leading companies link profit and growth to loyalty, satisfaction and value. New York: The Free Press.

Holbrook, M. 1996. 'Customer value-A framework for analysis and research'. In Corfman. K.P. \& Lynch, J.G. (Jr), (Eds). Advances in consumer research, 23:138-142. Provo, UT: Association for Consumer Research.

Iniesta, M.A. \& Sánchez, M. 2002. 'Retail-consumer commitment and market segmentation', The International 
Review of Retail, Distribution and Consumer Research, 12(3): 261-279.

Jensen, H.R. 1996. 'The interrelationship between customer and consumer value', Asia Pacific Advances in Consumer Research, 2: 60-63.

Johnson, M.D. \& Ettlie, J.E. 2001. 'Technology, customization, and reliability', Journal of Quality Management, 6(2): 193-210.

Johnson, M.D. \& Fornell, C. 1991. 'A framework for comparing customer satisfaction across individuals and product categories', Journal of Economic Psychology, 12 (2): 267-286.

Johnson, M.D., Gustafsson, A., Andreasen, T.W., Lervik, L. \& Cha, J. 2001. 'The evaluation and future of national customer satisfaction index models', Journal of Economic Psychology, 22(2): 217-245.

Johnson, M.D. \& Nilsson, L. 2000. The impact of reliability and customization on customer satisfaction for goods versus services. University of Michigan Business School, Ann Arbor, MI Working Paper No. 00-027.

Jöreskog, K.G. \& Sörbom, D. 2006. LISREL 8.80 for Windows [Computer Software]. Lincolnwood, IL: Scientific Software International, Inc.

Kent, E. \& Löfmarck Vaghult, A. 2000. 'Customer retention, purchasing behavior and relationship substance in professional services', Industrial Marketing Management, 29(4): 363-372.

Knox, S. D. \& Denison, T. J. 2000. 'Store loyalty: Its impact on retail revenue. An empirical study of purchasing behavior in the UK', Journal of Retailing and Consumer Services, 7(1): 33-45.

Kumar, A. \& Grisaffe, D.B. 2004. 'Effects of extrinsic attributes on perceived quality, customer value, and behavioral intentions in B2B settings: A comparison across goods and service industries', Journal of Business-toBusiness Marketing, 11(4): 43-74.

Kwate, N.O.A. 2008. 'Fried chicken and fresh apples: Racial segregation as a fundamental cause of fast food density in black neighborhoods', Health \& Place, 14(1): 3244.

Lai, A.W. 1995. 'Consumer values, product benefits and customer value: A consumption behavior approach', Advances in Consumer Research, 22(1): 381-388.

Lin, C-H., Sher, P.J. \& Shih, H-Y. 2005. 'Past progress and future directions in conceptualising customer perceived value', International Journal of Service Industry Management, 16(4): 318-336.

Liu, C-M. 2005. 'The multidimensional and hierarchical structure of perceived quality and customer satisfaction', International Journal of Management, 22(3): 426-435.
Mackay, H. 1999. Turning point: Australians choosing their future. Sydney: MacMillan.

Miranda, M.J., Kónya, L. \& Havrila, I. 2005. 'Shoppers' satisfaction levels are not the only key to store loyalty', Marketing Intelligence and Planning, 23(2): 220-232.

Mittal, B. \& Lassar, W.M. 1998. 'Why do customers switch? The dynamics of satisfaction versus loyalty', The Journal of Services Marketing, 12(3): 177-194.

Mittal, V. \& Kamakura, W. A. 2001. 'Satisfaction, repurchase intent, and repurchase behavior: Investigating the moderating effect of customer characteristics', Journal of Marketing Research, 38(1): 131-142.

Nilson, T.H. 1992. Value-added marketing: Marketing management for superior results. Berkshire: McGraw-Hill.

Nunnally, J.C. \& Bernstein, I.H. 1994. Psychometric theory. New York: McGraw-Hill.

Oliver, R.L. 1999. 'Whence consumer loyalty?', Journal of Marketing, 63(4): 33-44.

Olsen, L.V. \& Johnson, M.D. 2003. 'Service equity, satisfaction, and loyalty: From transaction specific to cumulative evaluations', Journal of Service Research, 5(3): 184-195.

Ostrom, A. \& Iacobucci, D. 1995. 'Consumer trade-offs and the evaluation of services', Journal of Marketing, 59(1): 1728.

Podoshen, J.S. 2008. 'The African-American consumer revisited: Brand loyalty, word-of-mouth and the effects of the black experience', Journal of Consumer Marketing, 25(4): 211-222.

Rangaswamy, A., Burke, R. R. \& Oliva, T. A. 1993. 'Brand equity and the extendibility of brand names', International Journal of Research in Marketing, 10(1): 61-75.

Reichheld, F. 1996. The loyalty effect: The hidden force behind growth, profit and lasting value. Boston: Harvard Business School Press.

Sousa, R. \& Voss, C.A. 2002. 'Quality management revisited: A reflective review and agenda for future research', Journal of Operations Management, 20(1): 91109.

Sweeney, J.C. \& Soutar, G.N. 2001. 'Consumer perceived value: The development of a multiple item scale', Journal of Retailing, 77(2): 203-220.

Treadgold, A. 1999. 'The outlook for Asian retailing', Discount Merchandiser, 39(5): 45-46.

Uncles, M.D., Dowling, G.R. \& Hammond, K. 2003. 'Customer loyalty and customer loyalty programs', Journal of Consumer Marketing, 20(4): 294-316. 
Wetzels, M., De Ruyter, K. \& Van Birgelen, M. 1998. 'Marketing service relationships: The role of commitment', Journal of Business \& Industrial Marketing, 13(4/5):406423.

Wirtz, B. W. \& Lihotzky, N. 2003. 'Customer retention management in the B2C electronic business', Long Range Planning, 36(6): 517-532.

Woodruff, B.R. \& Gardial, F.S. 1996. Know your customer: New approaches to understanding customer value and satisfaction. Malden: Blackwell Business.

Woodruff, R.B. 1997. 'Customer value: The next source for competitive advantage', Journal of the Academy of Marketing Science, 25(2): 139-153.

Zeithaml, V.A. 1988. 'Consumer perceptions of price, quality, and value: A means-end model and synthesis of evidence', Journal of Marketing, 52(3): 2-22.

Zeithaml, V.A. \& Bitner, M.J. 1996. Services marketing. New York: McGraw-Hill. 